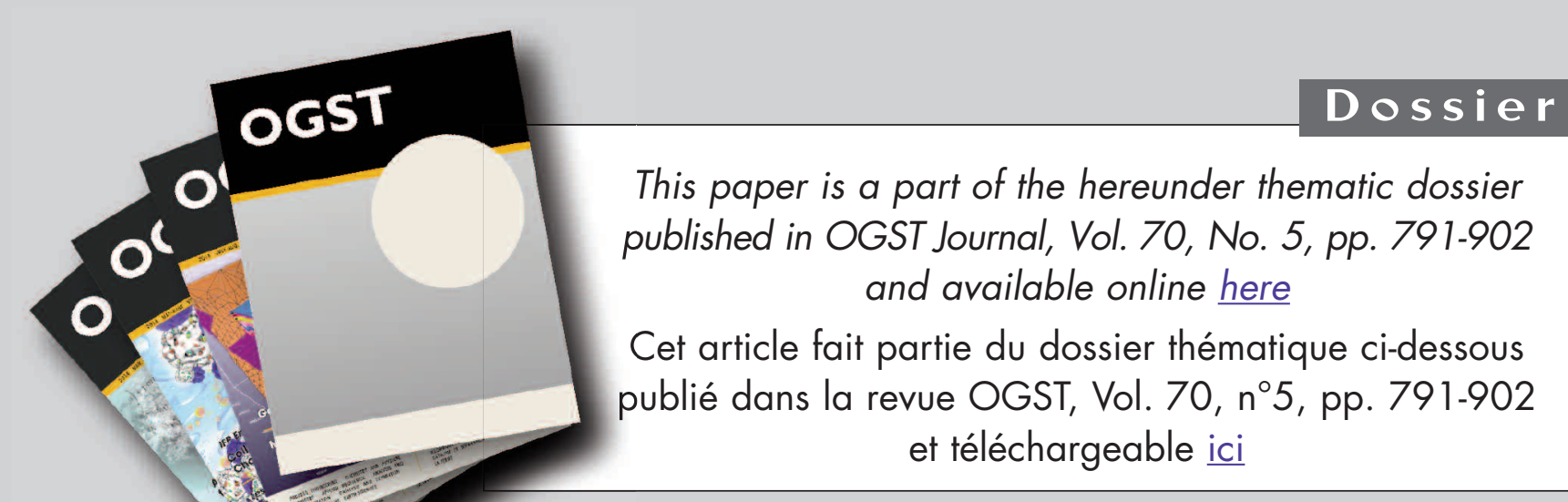

DOSSIER Edited by/Sous la direction de : D. Uzio

IFP Energies nouvelles International Conference / Les Rencontres Scientifiques d'IFP Energies nouvelles

$$
\begin{gathered}
\text { PHOTO4E - Photocatalysis for energy } \\
\text { PHOTO4E - Photocatalyse pour l'énergie }
\end{gathered}
$$

Oil \& Gas Science and Technology - Rev. IFP Energies nouvelles, Vol. 70 (2015), No. 5, pp. 791-902

Copyright (C) 2015, IFP Energies nouvelles

$791>$ Editorial

M. Fontecave, A. Fécant and D. Uzio

$799>$ Solar Production of Fuels from Water and $\mathrm{CO}_{2}$ : Perspectives and Opportunities for a Sustainable Use of Renewable Energy

Production solaire de carburants à partir de l'eau et de $\mathrm{CO}_{2}$ : perspectives et opportunités pour une utilisation durable de l'énergie renouvelable

R. Passalacqua, G. Centi and S. Perathoner

817 > Effect of Post-Synthesis Treatments on the Properties of ZnS Nanoparticles: An Experimental and Computational Study

Effet des traitements après-synthèse sur les propriétés de nanoparticules de ZnS : une étude expérimentale et computationnelle

E. Balantseva, B. Camino, A.M. Ferrari and G. Berlier

831 > Comparative Study on The Photocatalytic Hydrogen Production from Methanol over $\mathrm{Cu}_{-}, \mathrm{Pd}$-, Co- and Au-Loaded TiO

Étude comparative de production d'hydrogène par photocatalyse à partir de méthanol et à l'aide de différentes phases actives ( $\mathrm{Cu}, \mathrm{Pd}, \mathrm{Co}$ et Au) supportées sur TiO

P.P.C. Udani and M. Rønning

841 > Photocatalytic Conversion of Carbon Dioxide Using Zn-Cu-Ga Layered Double Hydroxides Assembled with Cu Phthalocyanine: Cu in Contact with Gaseous Reactant is Needed for Methanol Generation

Conversion photocatalytique du dioxyde de carbone par des hydroxydes doubles lamellaires de Zn-Cu-Ga promus par la phtalocyanine de Cu : nécessité du contact entre le Cu et le réactif gazeux pour la synthèse du méthanol

S. Kawamura, N. Ahmed, G. Carja and Y. Izumi
$853>$ Recyclable PhotoFuel Cell for Use of Acidic Water as a Medium Cellule photocombustible recyclable pour I'utilisation d'eau acide en tant que milieu

Y. Ogura, M. Yoshiba, and Y. Izumi

$863>$ Solar Hydrogen Reaching Maturity L'hydrogène solaire arrive à maturité

J. Rongé, T. Bosserez, L. Huguenin, M. Dumortier, S. Haussener and J.A. Martens

877 > Design of Compact Photoelectrochemical Cells for Water Splititing Conception de cellules photoélectrochimiques compactes pour la décomposition de l'eau

T. Bosserez, J. Rongé, J. van Humbeeck, S. Haussener and J. Martens

891 > Simultaneous Production of $\mathrm{CH}_{4}$ and $\mathrm{H}_{2}$ from Photocatalytic Reforming of Glucose Aqueous Solution on Sulfated Pd-TiO, Catalysts Production simultanée de $\mathrm{CH}_{4}$ et $\mathrm{H}_{2}$ par réformage photocatalytique d'une solution aqueuse de glucose sur un catalyseur Pd-TiO, sulfaté V. Vaiano, G. lervolino, G. Sarno, D. Sannino, L. Rizzo, J.J. Murcia Mesa, M.C. Hidalgo and J.A. Navío 


\title{
Recyclable PhotoFuel Cell for Use of Acidic Water as a Medium
}

\author{
Yuta Ogura, Mao Yoshiba and Yasuo Izumi* \\ Department of Chemistry, Graduate School of Science, Chiba University, Yayoi 1-33, Inage-ku, Chiba 263-8522 - Japan \\ e-mail: tyojuryoku@hotmail.co.jp - yubari.com@ae.auone-net.jp - yizumi@faculty.chiba-u.jp \\ * Corresponding author
}

\begin{abstract}
We reported a new PhotoFuel Cell (PFC) comprising two photocatalysts for use of acidic water as a recyclable medium. Nitrogen and oxygen flow was required in the photoanode and photocathode, respectively. In this study, we developed a gas-circulating PFC that needs no gas supply from outside. In the gas-circulating PFC, the reverse reaction of water oxidation at the anode was prevented by the gas flow of photogenerated $\mathrm{O}_{2}$ from the anode to the cathode inside the PFC. The gas-circulating PFC accommodated an organic solvent layer over the aqueous electrolyte for the anode, and also a vent hole in the upper part of the Proton-Conducting Polymer (PCP) film. $\mathrm{O}_{2}$ transferred from the anode electrolyte to the organic solvent due to the solubility difference between the $\mathrm{HCl}$ solution and organic solvent. $\mathrm{O}_{2}$ transfer from the gas phase in the anode to that in the cathode was achieved by the vent hole in the PCP film due to the pressure difference due to the progress of the reaction. By the addition of a hexane layer to the anode of the PFC, it was demonstrated to achieve a photocurrent value of $69.7 \mu \mathrm{A}$ per $1.3 \mathrm{~cm}^{2}$ of photocatalysts. However, in the stability tests for more than $7 \mathrm{~h}$, the small amount of remaining $\mathrm{O}_{2}$ in the electrolyte $\left(2.85 \mu \mathrm{mol} \mathrm{L} \mathrm{L}^{-1}\right)$ exhibited serious effects on the PFC performance. The $I_{S C}, V_{O C}$ and $P_{M a x}$ values of the gas-circulating PFC were $29.2 \mu \mathrm{A}, 1.18 \mathrm{~V}$ and $6.10 \mu \mathrm{W}$, that were $40 \%, 74 \%$ and $44 \%$, respectively, of those for a $\mathrm{N}_{2}$ and $\mathrm{O}_{2}$ flow-type PFC. Apparently, photocurrents were dramatically suppressed by the reverse reaction at the photoanode in the extended tests for the gas-circulating PFC.
\end{abstract}

Résumé - Cellule photocombustible recyclable pour l'utilisation d'eau acide en tant que milieu - Nous décrivons une nouvelle cellule photocombustible (PhotoFuel Cell, PFC) comprenant deux photocatalyseurs utilisant de l'eau acide recyclée. Un flux d'azote et d'oxygène a été nécessaire dans respectivement la photoanode et la photocathode. Dans cette étude, nous avons développé une PFC à circulation de gaz qui n'a pas besoin d'être alimentée en gaz de l'extérieur. Dans la PFC à circulation de gaz, la réaction inverse d'oxydation de l'eau à l'anode a été évitée par le flux de gaz d' $\mathrm{O}_{2}$ photo-généré de l'anode à la cathode à l'intérieur de la PFC. La PFC à circulation de gaz présentait une couche de solvant organique au-dessus de l'électrolyte aqueux pour l'anode, et également un orifice d'aération dans la partie supérieure du film polymère conducteur de proton (Proton-Conducting Polymer, PCP). $\mathrm{L}^{\prime} \mathrm{O}_{2}$ était transféré de l'électrolyte de l'anode au solvant organique, à cause de la différence de solubilité entre la solution d' $\mathrm{HCl}$ et le solvant organique.

Le transfert d' $\mathrm{O}_{2}$ de la phase gazeuse à l'anode vers celle dans la cathode a été réalisé par l'orifice d'aération dans le film PCP, du fait de la différence de pression due à la progression de la réaction. En ajoutant une couche d'hexane à l'anode de la PFC, il a été démontré que l'on atteignait une valeur de courant photo-électrique de $69,7 \mu \mathrm{A}$ par $1,3 \mathrm{~cm}^{2}$ de photocatalyseurs. Toutefois, dans les tests de stabilité, pendant plus de $7 \mathrm{~h}$, la faible quantité d' $\mathrm{O}_{2}$ restant dans l'électrolyte $\left(2,85 \mu \mathrm{mol} \mathrm{L}^{-1}\right)$ a eu des 
effets importants sur les performances de la PFC. Les valeurs $I_{s c}, V_{o c}$ et $P_{M a x}$ de la PFC à circulation de gaz ont atteint $29,2 \mu \mathrm{A}, 1,18 \mathrm{~V}$, et $6,10 \mu \mathrm{W}$, soit $40 \%, 74 \%$ et $44 \%$, respectivement de celles d'une PFC de type à flux de $\mathrm{N}_{2}$ et d' $\mathrm{O}_{2}$. Apparemment, les courants photo-électriques ont été considérablement supprimés par la réaction inverse à la photoanode dans les tests prolongés pour la PFC à circulation de gaz.

\section{INTRODUCTION}

Fossil fuels have been utilized as the essential energy source for industrialization. Industrial $\mathrm{CO}_{2}$ emissions have led to an increase in the level of atmospheric $\mathrm{CO}_{2}$ concentration (400 ppm), and the effects of this increase on global warming cannot be underestimated. The development of renewable energy as a replacement for fossil fuels has been slow $[1,2]$.

Among the renewable energies, solar energy has the greatest potential. Although the Silicon Solar Cell (Si SC) has been commercialized, the technology that can convert solar energy to electricity often needs subsidies to spread more widely [3]. Other types of SC, e.g. the dye-sensitized $\mathrm{SC}$ and compound SC [4], and Fuel Cells (FC) that use hydrogen/methanol fuel [5-8], potentially obtained using solar energy [9], have been extensively investigated. However, all the requisites (sustainability, durability and an electromotive force of 1-3 V per cell) have not been fully satisfied.

Recently, a new device was demonstrated: a PFC utilizing two photocatalysts of $\mathrm{TiO}_{2}$ and silver(0/I)-doped $\mathrm{TiO}_{2}$ [10] on an electrode film, both immersed in acidic solutions separated by a PCP film [11]. Platinum is not used [5-8, 12-16], and only inexpensive materials were used in the PFC for sustainability. The PFC is similar to photoelectrochemical cells (PEC) consisting of a photoanode and a photocathode to form $\mathrm{O}_{2}$ and $\mathrm{H}_{2}$, respectively, from water $[17,18]$ and also PEC consisting of a photoanode to oxidize water [19] or organic dye fuel [20] and a photocathode to reduce protons. The PFC is different from these PEC in that the medium, water, is recycled in the cell and no fuel is needed except for natural light [21].

Although PFC enable higher electromotive force $(1.8 \mathrm{~V})$ $[11,21]$ and use only acidic water as a medium and inexpensive catalysts, PFC need a gas supply to promote surface reactions at both the anode and cathode. At the anode, $\mathrm{O}_{2}$ gas needs to be evacuated by $\mathrm{N}_{2}$ flow to prevent a reverse surface reaction:

$$
\mathrm{O}_{2}+4 \mathrm{H}^{+}+4 e^{-} \rightarrow 2 \mathrm{H}_{2} \mathrm{O}
$$

On the other hand, at the cathode reactant $\mathrm{O}_{2}$ should be supplied for the reaction (1) to proceed. Therefore, PFC need gas cylinders to supply these gases for effective power generation. This situation limits the design of compact enough PFC that can be accommodated in portable electronic devices.

Herein, we developed a PFC in which gas circulates internally. By circulating formed $\mathrm{O}_{2}$ gas from the anode to the cathode, the reverse reaction at the anode could be prevented. The concept of gas-circulating PFC is shown in Figure 1a, Test 3. The PFC has two photocatalysts $\left(\mathrm{TiO}_{2}\right.$ and $\mathrm{Ag}-\mathrm{TiO}_{2}$ ) immersed in $\mathrm{HCl}$ solution. The electrolyte at the anode and that at the cathode (Fig. 1b2,3) are separated by a PCP (Fig. 1b4, 5). As the mechanism of gas circulation, the PFC designed in this study comprises an organic solvent phase on an anode electrolyte (Fig. 1b1) and a vent hole in the upper part of the PCP film (Fig. 1b4, 5). The organic solvent can dissolve a greater amount of $\mathrm{O}_{2}$ gas than water can.

$\mathrm{O}_{2}$ gas circulated in the PFC as follows. $\mathrm{O}_{2}$ generated by the anode reaction transferred preferentially into the organic solvent due to the difference in $\mathrm{O}_{2}$ solubility between the $\mathrm{HCl}$ solution and the organic solvent. Then, the dissolved $\mathrm{O}_{2}$ in the organic solvent moved to the upper gas phase due to the increased $\mathrm{O}_{2}$ concentration in the solvent in the compartment of the anode, and then to the upper gas phase in the compartment of the cathode through the vent hole in the PCP film due to the pressure difference between the $\mathrm{O}_{2}$ formed at the anode and $\mathrm{O}_{2}$ consumed at the cathode (Fig. 1a, 1b1). Finally, the gaseous $\mathrm{O}_{2}$ that moved to the cathode side reached the photocatalyst on the cathode and was photoreduced.

\section{EXPERIMENTAL SECTION}

\subsection{Sample Preparation of the Photoelectrodes}

$\mathrm{TiO}_{2}$ powder $[1.00 \mathrm{~g} ; \mathrm{P} 25$, Degussa ; anatase/rutile phases $=$ $7 / 3$; Brunauer-Emmett-Teller (BET) surface area $\left(S_{\mathrm{BET}}\right)=$ $60 \mathrm{~m}^{2} \mathrm{~g}^{-1}$ ] was suspended in $3.0 \mathrm{~mL}$ of deionized water $\left(<0.06 \mu \mathrm{S} \mathrm{cm}{ }^{-1}\right)$ and then stirred well. The obtained suspension was dried at $373 \mathrm{~K}$ for $24 \mathrm{~h}$ and heated in air at $673 \mathrm{~K}$ for $2 \mathrm{~h}$. The resultant powder was suspended in $75 \mu \mathrm{L}$ of deionized water and placed on an Indium Tin Oxide (ITO, thickness 1.2-1.6 $\mu \mathrm{m}$ )-coated Pyrex glass plate. $\mathrm{The} \mathrm{TiO}_{2} / \mathrm{ITO} /$ Pyrex was dried at $373 \mathrm{~K}$ for $18 \mathrm{~h}$ and heated in air at $573 \mathrm{~K}$ for $30 \mathrm{~min}$. The amount of $\mathrm{TiO}_{2}$ deposited on the ITO-coated glass plate was $5.0 \mathrm{mg}$ and covered an area of $1.3 \mathrm{~cm}^{2}$. 

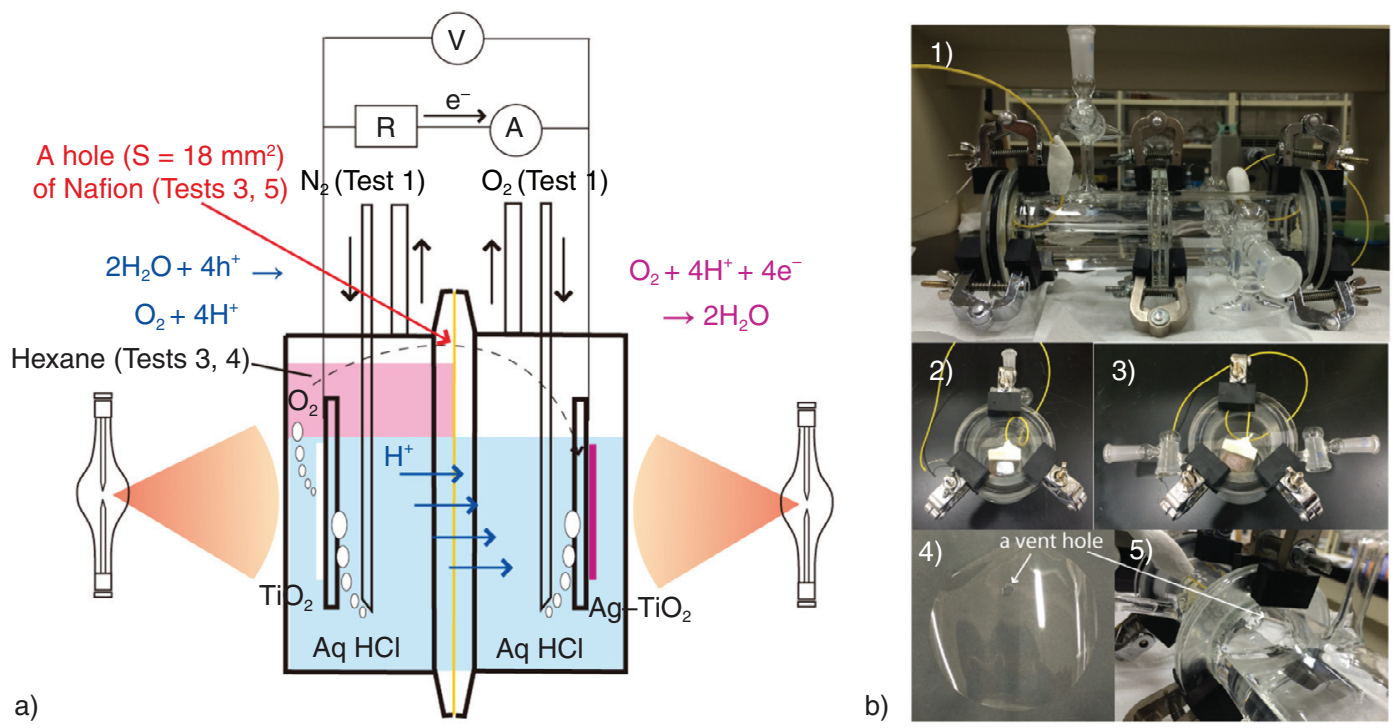

Figure 1

a) Components of the PFC comprising $\mathrm{TiO}_{2}$ and $\mathrm{Ag}-\mathrm{TiO}_{2}$ photocatalysts used for Tests 1-5. Oxidation by photogenerated holes at the anode and reduction by photogenerated electrons take place. Remaining electrons at the anode flow to the cathode and combine with the remaining holes. b) Photographs of the PFC for Test 3 (1). Photoanode side (2), photocathode side (3), and the PCP with a vent hole $(4,5)$.

Silver nitrate (159 mg; 99.8\%, Wako Pure Chemicals) was dissolved in $10 \mathrm{~mL}$ of deionized water. The solution was mixed with $3.33 \mathrm{~g}$ of untreated $\mathrm{TiO}_{2}(\mathrm{P} 25)$. The mixture was magnetically stirred at a rate of 850 rotations per minute (rpm) and the water was distilled at $353 \mathrm{~K}$. The obtained powder was dried at $373 \mathrm{~K}$ for $24 \mathrm{~h}$ and heated in air at $673 \mathrm{~K}$ for $2 \mathrm{~h}$. The resultant $\mathrm{Ag}-\mathrm{TiO}_{2}$ powders contained $3.0 \mathrm{wt} \%$ of Ag. They were suspended in a minimum amount of water and placed on ITO-coated glass $\left(\mathrm{Ag}-\mathrm{TiO}_{2} / \mathrm{ITO} /\right.$ Pyrex) in a manner similar to that for the $\mathrm{TiO}_{2} / \mathrm{ITO} /$ Pyrex.

\subsection{Photocurrent Tests}

\subsubsection{Test 1: Gas-Flow Conditions}

$\mathrm{TiO}_{2} / \mathrm{ITO} / \mathrm{Pyrex}$ and $\mathrm{Ag}-\mathrm{TiO}_{2} / \mathrm{ITO} / \mathrm{Pyrex}$ electrodes were immersed in $\mathrm{HCl}$ solutions $(40 \mathrm{~mL}$ in each compartment; initial $\mathrm{pH}$ 4.0-2.0). The two compartments were separated by a $50-\mu$ m-thick PCP film (Nafion, DuPont; acid capacity > $9.2 \times 10^{-4}$ equivalent $\mathrm{g}^{-1}$ ). $\mathrm{N}_{2}$ (purity $>99.999 \%$ ) and $\mathrm{O}_{2}$ gases (purity $>99.6 \%$ ) were bubbled $30 \mathrm{~mm}$ away from each photoelectrode at a flow rate of $100 \mathrm{~mL} \mathrm{~min}^{-1}$ (Fig. 1a). The PFC was equipped with quartz windows $(\phi=80 \mathrm{~mm})$ on both sides. Both the $\mathrm{TiO}_{2}$ and $\mathrm{Ag}-\mathrm{TiO}_{2}$ photocatalysts were irradiated with UV-visible light through the quartz windows using a two-way branched quartz fiber light guide (Model 5 $\phi-2 \mathrm{~B}-1000 \mathrm{~L}$, San-ei Electric Co.) from a 500-W xenon arc lamp (Model SX-UID502XAM, Ushio).
The distance between the light exit $(\phi=5 \mathrm{~mm})$ and the $\mathrm{TiO}_{2}$ or $\mathrm{Ag}-\mathrm{TiO}_{2}$ film was $46 \mathrm{~mm}$. The light intensity was $8 \mathrm{~mW} \mathrm{~cm}{ }^{-2}$ at the center of the photocatalyst film on each electrode.

\subsubsection{Test 2: Gas-Closed Conditions}

PFC comprising $\mathrm{TiO}_{2} / \mathrm{ITO} /$ Pyrex and $\mathrm{Ag}-\mathrm{TiO}_{2} / \mathrm{ITO} / \mathrm{Pyrex}$ electrodes were prepared and immersed in $\mathrm{HCl}$ solutions ( $40 \mathrm{~mL}$ in each compartment; initial $\mathrm{pH} 2.0$ ) in a similar procedure to that in Test 1 . The two compartments were separated by a $50-\mu \mathrm{m}$-thick PCP film. $\mathrm{N}_{2}$ and $\mathrm{O}_{2}$ gases purged the compartments of $\mathrm{TiO}_{2} / \mathrm{ITO} / \mathrm{Pyrex}$ and $\mathrm{Ag}-\mathrm{TiO}_{2} / \mathrm{ITO} / \mathrm{Pyrex}$, but the gas supply was stopped before the start of Test 2. Both the $\mathrm{TiO}_{2}$ and $\mathrm{Ag}-\mathrm{TiO}_{2}$ photocatalysts were irradiated with UV-visible light in the closed compartments filled with $\mathrm{N}_{2}$ and $\mathrm{O}_{2}$, respectively.

\subsubsection{Test 3: Gas-Circulating Conditions inside the PFC}

$\mathrm{An} \mathrm{Ag}-\mathrm{TiO}_{2} / \mathrm{ITO} /$ Pyrex electrode was immersed in $50 \mathrm{~mL}$ of $\mathrm{HCl}$ solution (initial $\mathrm{pH} 2.0$ ), whilst $\mathrm{TiO}_{2} / \mathrm{ITO} /$ Pyrex was immersed in $50 \mathrm{~mL}$ of the $\mathrm{HCl}$ solution phase (initial $\mathrm{pH} 2.0$ ) and $50 \mathrm{~mL}$ of hexane phase was added above the $\mathrm{HCl}$ solution phase (Fig. 1). All the area of the $\mathrm{TiO}_{2}$ film was immersed in the $\mathrm{HCl}$ solution phase and not in contact with the hexane phase. $\mathrm{N}_{2}$ and $\mathrm{O}_{2}$ gases purged the compartments of $\mathrm{TiO}_{2} / \mathrm{ITO} /$ Pyrex and $\mathrm{Ag}-\mathrm{TiO}_{2} / \mathrm{ITO} /$ Pyrex, 
TABLE 1

The conditions for current tests of the PFC

\begin{tabular}{c|c|c|c}
\hline Test & $\begin{array}{c}\mathrm{N}_{2} / \mathrm{O}_{2} \\
\text { supply }\end{array}$ & Hexane@anode & $\begin{array}{c}\text { Vent hole@PCP } \\
\text { film }\end{array}$ \\
\hline 1 & $\circ$ & $\times$ & $\times$ \\
\hline 2 & $\times$ & $\times$ & $\times$ \\
\hline 3 & $\times$ & $\circ$ & $\bigcirc$ \\
\hline 4 & $\times$ & $\circ$ & $\times$ \\
\hline 5 & $\times$ & $\times$ & $\bigcirc$ \\
\hline
\end{tabular}

respectively, but the gas supply was stopped before the start of Test 3. Both the $\mathrm{TiO}_{2}$ and $\mathrm{Ag}-\mathrm{TiO}_{2}$ photocatalysts were irradiated with UV-visible light, set in the closed compartments filled with $\mathrm{N}_{2}$ and $\mathrm{O}_{2}$, respectively. The two compartments were separated by a $50-\mu \mathrm{m}$-thick PCP film; however, in Test 3, gas circulation inside the PFC was enabled through a vent hole $(6.0 \mathrm{~mm} \times 3.0 \mathrm{~mm})$ in the upper part of the PCP film (Fig. 1a, b4, b5) from the anode compartment in which $\mathrm{O}_{2}$ was formed to the cathode compartment in which $\mathrm{O}_{2}$ was consumed. The conditions of UV-visible light irradiation were similar to those for Tests 1 and 2 (Tab. 1).

\subsubsection{Test 4: Gas-Closed Conditions Plus Hexane@Anode}

An $\mathrm{Ag}_{-} \mathrm{TiO}_{2} / \mathrm{ITO} /$ Pyrex electrode was immersed in $55 \mathrm{~mL}$ of $\mathrm{HCl}$ solution (initial $\mathrm{pH} 2.0$ ), whilst $\mathrm{TiO}_{2} / \mathrm{ITO} / \mathrm{Pyrex}$ was immersed in $55 \mathrm{~mL}$ of the $\mathrm{HCl}$ solution phase (initial $\mathrm{pH} 2.0$ ) and $55 \mathrm{~mL}$ of the hexane phase above the $\mathrm{HCl}$ solution phase (Fig. 1). All the area of the $\mathrm{TiO}_{2}$ film was immersed in the $\mathrm{HCl}$ solution phase and not in contact with the hexane phase. $\mathrm{N}_{2}$ and $\mathrm{O}_{2}$ gases purged the compartments of $\mathrm{TiO}_{2} / \mathrm{ITO} / \mathrm{Pyrex}$ and $\mathrm{Ag}-\mathrm{TiO}_{2} / \mathrm{ITO} /$ Pyrex, respectively, but the gas supply was stopped before the start of Test 4 . Both the $\mathrm{TiO}_{2}$ and $\mathrm{Ag}-\mathrm{TiO}_{2}$ photocatalysts were irradiated with UV-visible light, set in the closed compartments filled with $\mathrm{N}_{2}$ and $\mathrm{O}_{2}$, respectively. The two compartments were separated by a $50-\mu \mathrm{m}$-thick PCP film. The film was complete and did not comprise any vent holes as in Test 3 . The conditions of UV-visible light irradiation were similar to those for Tests 1-3 (Tab. 1).

\subsubsection{Test 5: Gas-Circulating Conditions inside the PFC Minus Hexane@Anode}

An $\mathrm{Ag}-\mathrm{TiO}_{2} / \mathrm{ITO} /$ Pyrex electrode was immersed in $40 \mathrm{~mL}$ of $\mathrm{HCl}$ solution (initial $\mathrm{pH} 2.0$ ), whilst $\mathrm{TiO}_{2} / \mathrm{ITO} /$ Pyrex was immersed in $40 \mathrm{~mL}$ of the $\mathrm{HCl}$ solution phase (initial $\mathrm{pH}$ 2.0). $\mathrm{N}_{2}$ and $\mathrm{O}_{2}$ gases purged the compartments of $\mathrm{TiO}_{2} / \mathrm{ITO} /$ Pyrex and $\mathrm{Ag}-\mathrm{TiO}_{2} / \mathrm{ITO} / \mathrm{Pyrex}$, respectively, but

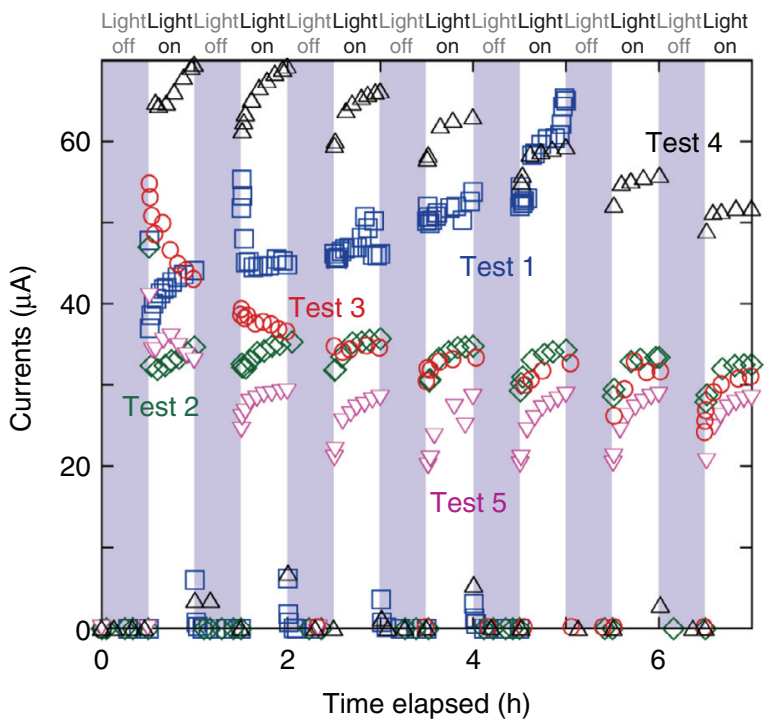

Figure 2

The time course of photocurrents of the PFC comprising $\mathrm{TiO}_{2}$ and $\mathrm{Ag}-\mathrm{TiO}_{2}$ photocatalysts in Tests 1 (gas flow), 2 (gas closed), 3 (gas circulating inside the PFC), 4 (gas-closed conditions plus hexane@anode), and 5 (gas-circulating conditions inside the PFC minus hexane@anode). The pH values of the electrolytes in both the anode and cathode were 2.0.

the gas supply was stopped before the start of Test 5 . Both the $\mathrm{TiO}_{2}$ and $\mathrm{Ag}-\mathrm{TiO}_{2}$ photocatalysts were irradiated with UV-visible light, set in the closed compartments filled with $\mathrm{N}_{2}$ and $\mathrm{O}_{2}$, respectively. The two compartments were separated by a $50-\mu \mathrm{m}$-thick PCP film. The conditions of UVvisible light irradiation were similar to those for Tests 1-4. This PFC had a vent hole $(6.0 \mathrm{~mm} \times 3.0 \mathrm{~mm})$ in the upper part of the PCP film (Fig. 1a, b4, b5) similar to Test 3 (Tab. 1).

For Tests 1-5, photocurrent generation (photocurrent tests) was performed by connecting the external parallel circuit for one route via a voltmeter and another route via an ammeter with a resistance of $0.5 \Omega$ (Fig. 1a). Both catalysts were exposed for $30 \mathrm{~min}$ to UV-visible light and then kept in the dark for $30 \mathrm{~min}$, and this process was repeated five-seven times. The current and voltage between the two electrodes were monitored.

\subsection{Current-Voltage Dependence Tests}

The current $(i)$-voltage $(V)$ characteristics were also measured for several types of PFC using a similar parallel circuit (Fig. 1a). After the photocurrent test for Figure 2 (2.5, 3.5 and $3.5 \mathrm{~h}$ of irradiation of UV-visible light for Tests 1,2 and 4 , respectively), the resistance was gradually decreased from $500 \mathrm{k} \Omega$ to $0.3 \Omega$ over $20 \mathrm{~min}$ to plot the $i-V$ dependence. For comparison, a PFC in the conditions of Test 1 
(Sect. 1.2.1) was also prepared and $i-V$ characteristics were also measured similar to the experiments described above, but in darkness.

\subsection{Product Analyses during Photocurrent Tests at the Anode}

\subsubsection{Analysis of $\mathrm{O}_{2}$ Formed at the Anode}

$56.2 \mathrm{mg}$ of iron(III) chloride hexahydrate (Kanto Chemical, purity $\geq 99 \%$ ) was dissolved in $90 \mathrm{~mL}$ of $\mathrm{HCl}$ aqueous solution in a quartz flask. The $\mathrm{pH}$ of this solution was adjusted to 2.0 by the addition of $\mathrm{HCl}$ solution. $151 \mathrm{mg}$ of $\mathrm{TiO}_{2}$ powder (P25, Degussa) was suspended in this solution for $10 \mathrm{~min}$. Then, dissolved $\mathrm{O}_{2}$ in the solution was removed by $\mathrm{N}_{2}$ bubbling for $30 \mathrm{~min}$. Next, $\mathrm{N}_{2}$ bubbling was stopped and the flask was isolated. The solution suspended with $\mathrm{TiO}_{2}$ was irradiated with UV-visible light from model SX-UID502XAM. The distance between the light exit $(\phi=60 \mathrm{~mm})$ and the center of the flask was $120 \mathrm{~mm}$. The sample was exposed to the light for $15 \mathrm{~min}$ and kept in the dark for $15 \mathrm{~min}$. This step was repeated five times. The solution was magnetically stirred at a rate of $1000 \mathrm{rpm}$ and the temperature was $298-301 \mathrm{~K}$. The formed $\mathrm{O}_{2}$ as dissolved was monitored in situ by a Dissolved Oxygen (DO) electrode (Model 9520-10D, Horiba).

\subsubsection{Analysis of Hypochlorous Acid Formed at the Anode by the Photooxidation of $\mathrm{Cl}^{-}$}

The possibility of the photooxidation of $\mathrm{Cl}^{-}$ions at the anode of the PFC instead of the photooxidation of water was checked. If $\mathrm{Cl}_{2}$ is formed by the photoxidation at the anode (Eq. 2), it should immediately decompose into hypochlorous acid and hydrochloric acid in the $\mathrm{HCl}$ solution of the anode (Eq. 3):

$$
\begin{gathered}
2 \mathrm{Cl}^{-}+2 h^{+} \rightarrow \mathrm{Cl}_{2} \\
\mathrm{Cl}_{2}+\mathrm{H}_{2} \mathrm{O} \rightarrow \mathrm{HCl}+\mathrm{HClO}
\end{gathered}
$$

The $\mathrm{HClO}$ formed was evaluated by the $N, N$-Diethyl- $p$ PhenyleneDiamine (DPD) method [22].

$20 \mathrm{mg}$ of DPD reagent $(0.8 \mathrm{mg}$ of DPD sulfate salt $\left(\mathrm{H}_{2} \mathrm{SO}_{4}\right)$ and $19.2 \mathrm{mg}$ of $\left.\mathrm{Na}_{2} \mathrm{SO}_{4}\right)$ were dissolved in $1.0 \mathrm{~mL}$ phosphate buffer solution $(\mathrm{pH}$ 6.5). This solution was mixed with $5.0 \mathrm{~mL}$ of $0-39.0 \mu \mathrm{mol} \mathrm{L}{ }^{-1}$ of $\mathrm{NaOCl}$ aqueous solutions and used as a standard solution. The mixed solutions $(6.0 \mathrm{~mL})$ were used to obtain a linear regression relationship between the absorbance at $515 \mathrm{~nm}$ and the concentration of $\mathrm{ClO}^{-}$ions.

Next, $20 \mathrm{mg}$ of DPD reagent were dissolved in $4.0 \mathrm{~mL}$ phosphate buffer solution ( $\mathrm{pH}$ 6.5). This solution was mixed with $2.0 \mathrm{~mL}$ of sample solution ( $\mathrm{HCl}$ aqueous solution) after a photocurrent Test 1 using a PFC (Fig. 1) for $3 \mathrm{~h}$ at $\mathrm{pH} 2.0$. The UV-visible spectrum of the mixed solution $(6.0 \mathrm{~mL})$ was measured by UV-visible spectrometer (Model V650, $J A S C O$ ). The concentration of $\mathrm{HClO}$ in the sample was determined based on the absorbance at $515 \mathrm{~nm}$ and the relationship obtained using $\mathrm{NaOCl}$ standard solutions. The reason for the volume difference for the phosphate buffer and sample solutions was to adjust the $\mathrm{pH}$ within 6.4 and 6.6 for mixed solutions $(6.0 \mathrm{~mL})$.

\section{RESULTS AND DISCUSSION}

\subsection{Photocurrent Tests}

The time courses of the photocurrent tests are summarized in Figure 2. For Test 1, in response to the UV-visible irradiation, photocurrents gradually increased from 43.7 to $60.5 \mu \mathrm{A}$ in five cycles at $\mathrm{pH} 2.0$. In contrast, the photocurrents increased and converged to a constant value $(26.7 \mu \mathrm{A})$ in the test at $\mathrm{pH} 3.0$ (not shown) [11]. Thus, the active metallic $\mathrm{Ag}^{0}$ species for photoreduction of $\mathrm{O}_{2}$ at the cathode should gradually increase, transformed from $\mathrm{Ag}_{2} \mathrm{O}$ by the reaction with protons, in the five cycles at $\mathrm{pH} 2.0$. The transformation of the active $\mathrm{Ag}$ species $\left(\mathrm{Ag}^{0}, \mathrm{Ag}_{2} \mathrm{O}\right.$ and $\left.\mathrm{AgCl}\right)$ was reported based on an extended $\mathrm{X}$-ray absorption fine-structure study [11].

At $\mathrm{pH} 4.0$, a PFC current of $3 \mu \mathrm{A}$ was obtained (not shown) for $2.5 \mathrm{~h}$ irradiated by UV-visible light $\left(0.28 \mu \mathrm{mol}-e^{-}\right.$generated in total) [11]. The $\mathrm{pH}$ values starting from 4.0 for the $\mathrm{HCl}$ solution $\left(40 \mathrm{~mL}, 4.0 \mu \mathrm{mol}-\mathrm{H}^{+}\right)$ remained constant after the PFC test at both the anode and cathode. The $\mathrm{pH}$ change due to each half reaction was calculated as \pm 0.03 . As this value is nearly the accuracy of $\mathrm{pH}$ monitoring under these conditions, we cannot judge that the photooxidation of water (at the anode) and photoreduction of $\mathrm{O}_{2}$ (at the cathode) exclusively took place. The possibility of a by-reaction, e.g. the consumption of acid, remained. For the test at $\mathrm{pH} 2.0$, the initial proton concentration was $400 \mu \mathrm{mol}$ in $40 \mathrm{~mL}$ of electrolyte solution at both the anode and cathode, while the PFC current for $2.5 \mathrm{~h}$ was $4.7 \mu$ mol- $-e^{-}$in total. The $\mathrm{pH}$ change due to each half reaction is calculated as \pm 0.005 . It was even more difficult to judge the possibility of photooxidation of water and/or anions of acid under the conditions.

In Test 2 , the photocurrent in the first cycle $(34.7 \mu \mathrm{A})$ was similar to that in Test $1(43.7 \mu \mathrm{A})$. In response to the UV-visible irradiation, photocurrents gradually increased to $35.8 \mu \mathrm{A}$ in three cycles. In contrast to the gradual increase in photocurrents throughout $5 \mathrm{~h}$ of the study in Test 1 , the photocurrents peaked at $35.8 \mu \mathrm{A}$ in the third cycle and gradually decreased to $32.2 \mu \mathrm{A}$ in the seventh cycle in Test 2 (Fig. 2). This decrease by $3.6 \mu \mathrm{A}$ suggested partial 
deactivation of the $\mathrm{TiO}_{2}$ photocatalyst at the anode. One of the major reasons is the reverse reaction of produced $\mathrm{O}_{2}$ which remained dissolved in the $\mathrm{HCl}$ solution to water (Eq. 1). In contrast to the gas-flowing Test 1 , the anode compartment of $\mathrm{TiO}_{2} / \mathrm{ITO} / \mathrm{Pyrex}$ was purged with $\mathrm{N}_{2}$ gas and produced $\mathrm{O}_{2}$ remained in the compartment for Test 2 (Tab. 1).

The photocurrent in the first cycle $(54.8-40.3 \mu \mathrm{A})$ was clearly higher in Test 3 than that in Tests 1 and 2. The photocurrent decreased to $36.5 \mu \mathrm{A}$ at the end of the second cycle (Fig. 2) and continued to decrease gradually to $31.0 \mu \mathrm{A}$ at the end of the seventh cycle. The photocurrents in the first cycle were probably higher because $\mathrm{N}_{2}$ was purged in the anode compartment more completely than in Tests 1 and 2 by the effect of hexane to preferably dissolve a contamination level of $\mathrm{O}_{2}(\sim 0.04 \mathrm{ppb})$. This evaluation was based on the impurity of $\mathrm{O}_{2}(<1 \mathrm{ppm})$ in the $\mathrm{N}_{2}$ gas used and the equilibrium of dissolution. Conversely, the decrease in the photocurrent in seven cycles suggested an even smaller amount of formed $\mathrm{O}_{2}$ remained in the anode and inhibited the PFC performance considerably, and also unexpected reverse diffusion of $\mathrm{O}_{2}$ from the cathode into the anode was not excluded through the vent hole.

In Test 4 , the photocurrent in the first cycle $(69.7 \mu \mathrm{A})$ was clearly higher than that in Tests 1-3. However, in response to the UV-visible irradiation, photocurrents gradually decreased to $51.9 \mu \mathrm{A}$ in seven cycles (Fig. 2). The photocurrent in Test 4 was always higher than that in Tests 2 and 3 throughout the photocurrent test. Thus, the positive effects of hexane on PFC were confirmed (Tab. 1), but unexpectedly, the vent hole in Test 3 contributed negatively to the photocurrent generation. Furthermore, the linear decrease of the photocurrent as a function of time that elapsed during Test 4 was more gradual than the exponential-like decrease as a function of time in Test 3 .

In Test 5, the photocurrent in the first cycle $(41.0-33.0 \mu \mathrm{A})$ was similar to that in Test 2 (Fig. 2). Then, it decreased to $29.2 \mu \mathrm{A}$ in the second cycle. Later than the third cycle, the photocurrents became stable at $28.4 \mu \mathrm{A}$. This stabilized current was lowest among the Tests $1-5$, as the result of produced $\mathrm{O}_{2}$ which remained dissolved in the $\mathrm{HCl}$ solution to water, and the unexpected reverse diffusion of $\mathrm{O}_{2}$ in the cathode into the anode through the vent hole, as in Test 3 (Tab. 1).

In Test 2, $1.11 \mu \mathrm{mol}$ of $\mathrm{O}_{2}$ were generated during the 7-h photocurrent test based on the total photocurrent for $3.5 \mathrm{~h}$ and assuming the next reaction (Eq. 1 is the reverse reaction of Eq. 4):

$$
2 \mathrm{H}_{2} \mathrm{O}+4 h^{+} \rightarrow \mathrm{O}_{2}+4 \mathrm{H}^{+}
$$

All of them were dissolved in the anode electrolyte based on the $\mathrm{O}_{2}$ solubility. Thus, the $\mathrm{O}_{2}$ concentration in the anode electrolyte was $27.8 \mu \mathrm{mol} \mathrm{L}^{-1}$. On the other hand, in Test 4, $2.01 \mu \mathrm{mol}$ of $\mathrm{O}_{2}$ were generated after the 7-h photocurrent

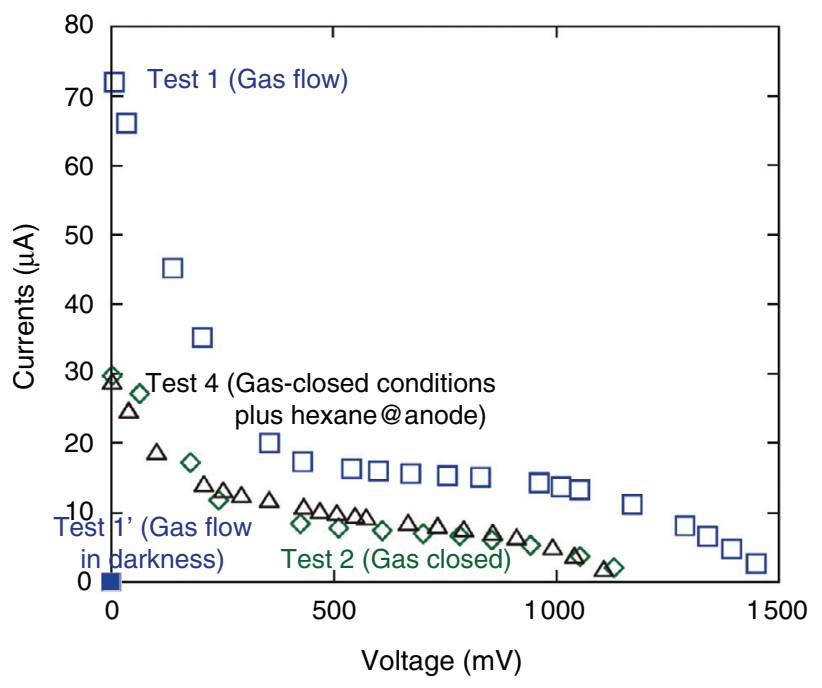

Figure 3

$i-V$ characteristics of the $\mathrm{PFC}$ comprising $\mathrm{TiO}_{2}$ and $\mathrm{Ag}-\mathrm{TiO}_{2}$ photocatalysts in Test 1 (gas flow), Test 2 (gas closed), Test 4 (gas-closed conditions plus hexane@anode), and control Test 1' in darkness (gas flow).

test based on the total photocurrent for $3.5 \mathrm{~h}$ and assuming reaction 4. In this test, the $\mathrm{O}_{2}$ should be distributed between the $\mathrm{HCl}$ solution and hexane. Based on the $\mathrm{O}_{2}$ solubility values in the literature to hydrochloric acid solution $\left(1.27 \mathrm{mmol} \mathrm{L}^{-1}\right)$ and to hexane $\left(15.0 \mathrm{mmol} \mathrm{L}^{-1}\right)$ [23], the distribution of $\mathrm{O}_{2}$ to hexane was calculated as:

$\frac{0.055 \mathrm{~L} \times 15 \mathrm{mmol} \mathrm{L}^{-1}}{0.055 \mathrm{~L} \times 1.27 \mathrm{mmol} \mathrm{L}^{-1}+0.055 \mathrm{~L} \times 15 \mathrm{mmol} \mathrm{L}^{-1}}=0.922$

Thus, 1.85 and $0.157 \mu \mathrm{mol} \mathrm{O}_{2}$ should be distributed to the hexane and $\mathrm{HCl}$ solutions, respectively, in equilibrium. Thus, the $\mathrm{O}_{2}$ concentration in the anode electrolyte ( $\mathrm{HCl}$ solution) was calculated as $2.85 \mu \mathrm{mol} \mathrm{L}{ }^{-1}$. Hence, the $\mathrm{O}_{2}$ concentration at the end of Test 4 was only $10 \%$ of that at the end of Test 2 . This difference accounted for the higher current density in Test 4 by a factor of two as compared with Test 2 (Fig. 2).

\section{2 i-V Characteristic Tests}

The obtained $i-V$ characteristics are shown in Figure 3. Furthermore, the properties of PFC calculated based on $i-V$ data in Tests 1, 2 and 4 are summarized in Table 2. In Test 1, the $i$ value gradually increased as the cell voltage decreased, starting from open circuit voltage $\left(V_{\mathrm{OC}}\right)$ at $1.59 \mathrm{~V}$, which is a similar trend to the $i-V$ dependence of the SC [24] or the Ohmic 
TABLE 2

PFC characteristics defined by $i-V$ characteristics in Tests 1 (gas flow), 2 (gas closed), and 3 (gas circulating inside the PFC)

\begin{tabular}{|c|c|c|c|}
\hline Test & $I_{\mathrm{SC}}(\mu \mathrm{A})$ & $V_{\mathrm{OC}}(\mathrm{V})$ & $P_{\text {Max }}(\mu \mathrm{W})$ \\
\hline 1 (Gas flow) & 73.7 & 1.59 & 14.0 \\
\hline 2 (Gas closed) & 29.8 & 1.23 & 5.5 \\
\hline 4 (Gas-closed conditions plus hexane@anode) & 29.2 & 1.18 & 6.1 \\
\hline 1' (Gas flow; control in darkness) & $<0.1$ & $<0.002$ & $<0.0002$ \\
\hline
\end{tabular}

loss region of a Polymer Electrolyte Fuel Cell (PEFC). When the voltage became less than $0.45 \mathrm{~V}$, the current increased linearly from 20 to $74 \mu \mathrm{A}$ (short-circuit current, $I_{\mathrm{SC}}$. This increasing trend was different from that in a SC or the transportation limit region of a PEFC [7, 8].

In Test 2, the shape of the $i-V$ characteristic curve was similar to that for Test 1 . However, the increase in currents in the lower voltage region $(\geq 0.45 \mathrm{~V})$ was less steep than the slope in Test 1 . The values of $I_{\mathrm{SC}}(29.8 \mu \mathrm{A}), V_{\mathrm{OC}}(1.23 \mathrm{~V})$ and $P_{\text {Max }}(5.51 \mu \mathrm{W})$ were 40,77 and $39 \%$ of the corresponding values obtained in Test 1 . The lower photocurrents in Test 2 suggested that the reverse reaction 1 that occurred in the anode seriously affected the performance of the PFC.

In Test 4 , the curve of $i-V$ characteristics was similar to that for Test 2; the increase in photocurrents in the lowvoltage region $(\geq 0.45 \mathrm{~V})$ was less steep than the slope in Test 1 . The values of $I_{\mathrm{SC}}(29.2 \mu \mathrm{A})$ and $V_{\mathrm{OC}}(1.18 \mathrm{~V})$ were slightly lower than the corresponding values in Test 2 , whilst the value of $P_{\mathrm{Max}}(6.10 \mu \mathrm{W})$ was clearly higher than that in Test $2(5.51 \mu \mathrm{W})$. This low performance (Fig. 3) was inconsistent with the better performance in photocurrent Test 4 than that in Tests 1 and 2 (Fig. 2). This trend cannot be rationalized based on the remaining amount of produced $\mathrm{O}_{2}$ dissolved in the anode. One of the possibilities is the polarization of photoelectrodes during the $i-V$ measurements at high voltage to modify the band bending (charge balance at the surface) at the surface of photocatalysts [25-29].

In a control Test 1' in darkness, the value of the current was always less than the detection limit by changing the resistance from $500 \mathrm{k} \Omega$ to $0.3 \Omega$. The corresponding voltage was less than $0.002 \mathrm{~V}$. Therefore, the values of $I_{\mathrm{SC}}, V_{\mathrm{OC}}$ and $P_{\text {Max }}$ were less than $0.1 \mu \mathrm{A}, 0.002 \mathrm{~V}$ and $0.0002 \mu \mathrm{W}$, respectively. This indicated electricity of the PFC was generated exclusively by irradiation with UV-visible light.

\subsection{Product Analyses during Photocurrent Tests at the Anode}

\subsubsection{Analysis of $\mathrm{O}_{2}$ Formed at the Anode}

The time course of dissolved $\mathrm{O}_{2}$ concentrations is shown in Figure 4. When $\mathrm{TiO}_{2}$ was irradiated with UV-visible light,

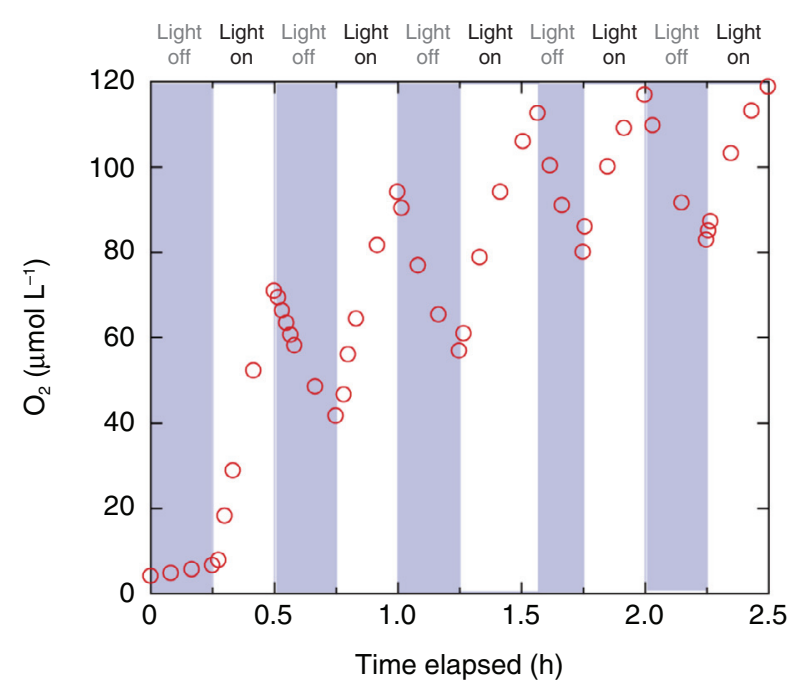

Figure 4

The time course of dissolved $\mathrm{O}_{2}$ concentrations during the photoirradiation test on $\mathrm{TiO}_{2}$. UV-visible light and $\mathrm{FeCl}_{3} \cdot 6 \mathrm{H}_{2} \mathrm{O}\left(2.31 \mathrm{mmol} \mathrm{L}{ }^{-1}\right)$ were used as excitation light and a sacrificial reagent, respectively. The initial $\mathrm{pH}$ value was 2.0 .

the dissolved $\mathrm{O}_{2}$ concentration linearly increased immediately in all five cycles. For $1.25 \mathrm{~h}$ irradiation, dissolved $\mathrm{O}_{2}$ was increased from $7.8 \mu \mathrm{mol} \mathrm{L}{ }^{-1}$ to $119 \mu \mathrm{mol} \mathrm{L}^{-1}$. If the irradiation was stopped, dissolved $\mathrm{O}_{2}$ decreased gradually in all cycles. This indicated that the formed $\mathrm{O}_{2}$ dissolved in acidic water and was transported to the gas phase in the quartz flask. In this photoreaction test, $151 \mathrm{mg}$ of $\mathrm{TiO}_{2}$ was used, significantly greater than the $5 \mathrm{mg}$ for the photocurrent test (Sect. 2.1, 2.2). Accordingly, a greater amount of $\mathrm{O}_{2}$ was generated from the water $\left(63.1 \mu \mathrm{mol} \mathrm{L}^{-1}\right.$ per $\left.0.25 \mathrm{~h}\right)$ in this photoreaction test than in photocurrent Test 2 $\left(27.8 \mu \mathrm{mol} \mathrm{L}^{-1}\right.$ per $\left.3.5 \mathrm{~h}\right)$. Thus, excessive $\mathrm{O}_{2}$ greater than the dissolution amount would be transported to the gas phase.

When the photocatalyst was irradiated, the rate would be the balance between $\mathrm{O}_{2}$ formation and the transportation to 
the gas phase. The increase in dissolved $\mathrm{O}_{2}$ in the first cycle was the quickest among all the cycles. The increase in dissolved $\mathrm{O}_{2}$ was $63.1 \mu \mathrm{mol} \mathrm{L}-1$ per $0.25 \mathrm{~h}$. The slope of the dissolved $\mathrm{O}_{2}$ gradually became less steep as the cycles were repeated. As a result, in the fifth cycle, it was $36.2 \mu \mathrm{mol} \mathrm{L}^{-1}$ per $0.25 \mathrm{~h}$. This trend is contradicted by the gradual increase in the photocurrent in Figure 2, Test 1 as the cycles repeated. We suspect that the major reason was that the transportation of dissolved $\mathrm{O}_{2}$ to the gas phase became faster as the concentration of dissolved $\mathrm{O}_{2}$ increased, as the cycles were repeated (Fig. 4).

The increase rate of dissolved $\mathrm{O}_{2}$ in the first cycle was:

$$
\begin{gathered}
63.1 \mu \mathrm{mol} \mathrm{L}-1 \times 0.090 \quad \mathrm{~L} / 0.25 \quad \mathrm{~h} / 0.151 \quad \mathrm{~g}_{\text {cat }} \\
=151 \mu \mathrm{mol}-\mathrm{O}_{2} \mathrm{~h}^{-1} \mathrm{~g}_{\text {cat }}^{-1}
\end{gathered}
$$

In comparison, the total photocurrent in Test 2 was average current:

$$
\begin{gathered}
34.0 \mu \mathrm{A} \times 3600 \mathrm{~s} \mathrm{~h}^{-1} / 9.65 \times 10^{4} \mathrm{~A} \mathrm{~s} \mathrm{mol-}-e^{-1} / 0.0050 \mathrm{~g}_{\text {cat }} \\
=253 \mu \mathrm{mol}-e^{-} \mathrm{h}^{-1} \mathrm{~g}_{\text {cat }}^{-1}
\end{gathered}
$$

The electron flow rate corresponded to the $\mathrm{O}_{2}$ generation rate of $63 \mu \mathrm{mol}-\mathrm{O}_{2} \mathrm{~h}^{-1} \mathrm{~g}_{\text {cat }}{ }^{-1}$. The net $\mathrm{O}_{2}$ generation rate in Figure 4 should be even higher because the $\mathrm{O}_{2}$ transported to the gas phase was not included for the evaluation in Figure 4. This difference in the amount based on the PFC current was not inconsistent. In the presence of a sacrificial oxidation agent, $\mathrm{Fe}^{3+}$, photoexcited electrons to the conduction band of $\mathrm{TiO}_{2}$ easily diffuse with sufficient $\mathrm{Fe}^{3+}$ and react in contrast so that the electrons need to travel to the cathode to react with holes at the valence band of $[\mathrm{Ag}-] \mathrm{TiO}_{2}$ in the PFC. The concentration of holes was determined by the balance of charge separation by light and the cathode reaction rate of $\mathrm{O}_{2}$ reduction $[11,21]$.

\subsubsection{Analysis of Hypochlorous Acid Formed at the Anode from $\mathrm{Cl}^{-}$lons}

The absorbance at $515 \mathrm{~nm}$ for standard mixed solutions $(6.0 \mathrm{~mL})$ was plotted as a function of $\mathrm{NaOCl}$ concentrations in the solution $(6.0 \mathrm{~mL})$. Then, a standard curve was calculated as follows (Fig. 5):

Absorbance@ $515 \mathrm{~nm}=0.0166 \times\left[\mathrm{ClO}^{-}\right]\left(\mu \mathrm{mol} \mathrm{L}^{-1}\right)+0.007$

$20 \mathrm{mg}$ of DPD reagent in $4.0 \mathrm{~mL}$ phosphate buffer solution ( $\mathrm{pH}$ 6.5) were mixed with $2.0 \mathrm{~mL}$ of sampled solution from the anode solution $(40 \mathrm{~mL})$ of the PFC after Test 1 for $3 \mathrm{~h}$. The absorbance of this mixed solution was $0.018 \pm 0.008$. Therefore, the amount of $\mathrm{HClO}$ in the mixed solution $(6.0 \mathrm{~mL})$ was $3.98 \mathrm{nmol}$ based in Equation (8).

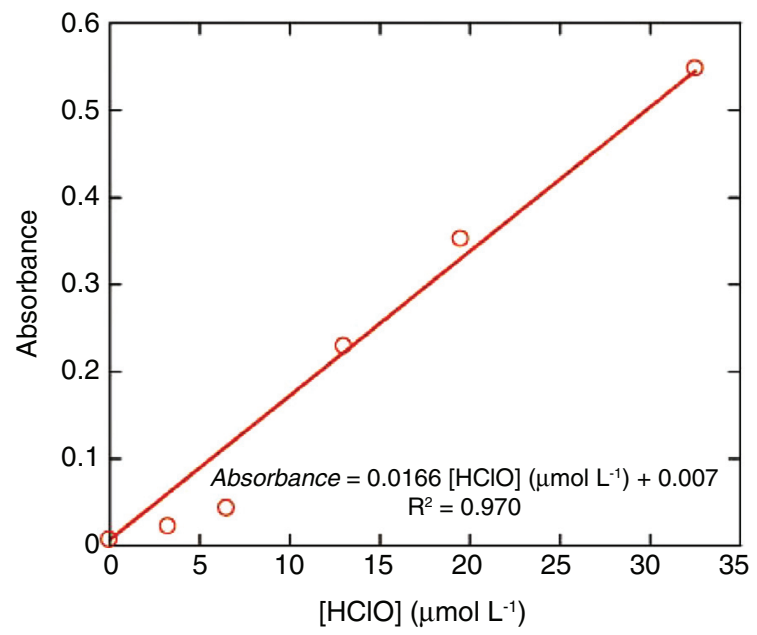

Figure 5

Absorbance at $515 \mathrm{~nm}$ for standard mixed solutions as a function of the concentration of $\mathrm{HClO}$ standard solutions.

Thus, the amount of $\mathrm{HClO}$ in the anode solution was calculated as:

$3.98 \mathrm{nmol} \times 40 \mathrm{~mL} / 2.0 \mathrm{~mL}=0.080 \pm 0.056 \mu \mathrm{mol}$

For $3 \mathrm{~h}$ of Test 1 (pH 2.0), total electron flow was 3.92 $\mu$ mol based on the integration of photocurrents. Two holes reacted with $\mathrm{Cl}^{-}$ions (Eq. 2) correspond to one $\mathrm{HClO}$ formed from $\mathrm{Cl}_{2}$ (Eq. 3). As the concentration of $\mathrm{HClO}$ was the impurity level for the anode solution in Test 1 , the amount of $\mathrm{HClO}$ was nearly the detection limit. Therefore, the upper limit of selectivity to proceed with Equation (2) for photogenerated holes was:

$$
2 \times 0.080 \mu \mathrm{mol}-\mathrm{HClO} / 3.92 \mu \mathrm{mol}-h^{+}=0.041 \pm 0.031
$$

The participation of chlorine ions in the anode reaction cannot be denied; however, the ratio was as low as $4.1 \%$ at most.

\section{CONCLUSIONS}

First, the anode reaction in the PFC was demonstrated exclusively to be the photooxidation of water over $\mathrm{TiO}_{2}$ based on the $\mathrm{O}_{2}$ evolution test, and negligible (or no) photooxidation of $\mathrm{Cl}^{-}$occurred based on the detected amount of $\mathrm{HClO}$. The selectivity of photooxidation of $\mathrm{Cl}^{-}$was $4.1 \%$ at most as compared with the photooxidation of water. Next, a product gas-trapping PFC was demonstrated to achieve a 
photocurrent value of $69.7 \mu \mathrm{A}$ per $1.3 \mathrm{~cm}^{2}$ of photocatalysts $\left(53.6 \mu \mathrm{A} \mathrm{cm}^{-2}\right)$. Gas trapping was enabled by accommodating an organic solvent layer over the aqueous electrolyte solution phase in the anode and utilizing the solubility difference of produced $\mathrm{O}_{2}$. However, gas circulation by a vent hole in the upper part of the PCP film due to pressure differences was not well achieved. To transfer generated $\mathrm{O}_{2}$ to an anode, a greater pressure difference was needed. The performance of the gas-closed PFC equipped with a hexane layer on the anode (Test 4) was the best at the initial stage of the photocurrent test due to the $\mathrm{O}_{2}$ solubility effect of hexane rather than the other conditions. However, the photocurrents gradually decreased during the measurements for $7 \mathrm{~h}$. The small amount of remaining $\mathrm{O}_{2}$ in the anode electrolyte $\left(2.85 \mu \mathrm{mol} \mathrm{L}^{-1}\right)$ reduced the PFC performance considerably in Test 4 . The $I_{\mathrm{SC}}, V_{\mathrm{OC}}$ and $P_{\mathrm{Max}}$ values of the gascirculating PFC were $29.2 \mu \mathrm{A}\left(22.5 \mu \mathrm{A} \mathrm{cm} \mathrm{cm}^{-2}\right), 1.18 \mathrm{~V}$ and $6.10 \mu \mathrm{W}\left(4.69 \mu \mathrm{W} \mathrm{cm}{ }^{-2}\right)$, respectively. These values were similar to corresponding values for the gas-closed PFC.

The feasibility of a gas-trapping PFC was successfully demonstrated in this study. Further, the improvement of power efficiency is required by the optimization of photocatalysts and the thickness and density of photocatalyst layers in order to be accommodated in portable electronic devices, remote-control light gliders, and environmental cameras/ sensors.

\section{ACKNOWLEDGMENTS}

The authors are grateful for financial support from the Feasibility Study Stage of A-STEP (AS262Z00159L, AS251Z00906L, AS231Z01459C) from the Japan Science and Technology Agency, the Iwatani Naoji Foundation (2011-2012), and a Grant-in-Aid for Scientific Research C (26410204, 22550117) from the Japan Society for the Promotion of Science. X-ray absorption experiments were conducted under the approval of the Photon Factory Proposal Review Committee (2013G159).

\section{REFERENCES}

1 Lewis N.S., Nocera D.G. (2006) Powering the Planet: Chemical Challenges in Solar Energy Utilization, Proc. Natl. Acad. Sci. USA 103, 15729.

2 Izumi Y. (2013) Recent Advances in the Photocatalytic Conversion of Carbon Dioxide to Fuels with Water and/or Hydrogen Using Solar Energy and Beyond, Coord. Chem. Rev. 257, 171.

3 Bolton J.R. (1996) Solar Photoproduction of Hydrogen: A review, Sol. Energy 57, 37.

4 Grätzel M. (2001) Photoelectrochemical Cells, Nature 414, 338.
5 Gasteiger H.A., Marković N.M. (2009) Just a Dream or Future Reality? Science 324, 48.

6 Schlapbach L. (2009) Hydrogen-Fuelled Vehicles, Nature 460, 809.

7 Oka K., Ogura Y., Izumi Y. (2014) X-Ray Evaluation of the Boundary between Polymer Electrolyte and Platinum and Carbon Functionalization to Conduct Protons in Polymer Electrolyte Fuel Cell, J. Power Sources 258, 83.

8 Oka K., Shibata Y., Itoi T., Izumi Y. (2010) Synthesis and Site Structure of a Replica Platinum-Carbon Composite Formed Utilizing Ordered Mesopores of Aluminum-MCM-41 for Catalysis in Fuel Cells, J. Phys. Chem. C 114, 1260.

9 Joya K.S., Joya Y.F., Ocakoglu K., van de Krol R. (2013) Water-Splitting Catalysis and Solar Fuel Devices: Artificial Leaves on the Move, Angew. Chem. Int. Ed. 52, 10426.

10 Seery M.K., George R., Floris P., Pillai S.C. (2007) Silver Doped Titanium Dioxide Nanomaterials for Enhanced Visible Light Photocatalysis, J. Photochem. Photobio. A 189, 258.

11 Ogura Y., Okamoto S., Itoi T., Fujishima Y., Yoshida Y., Izumi Y. (2014) A photofuel Cell Comprising Titanium Oxide and Silver(I/0) Photocatalysts for Use of Acidic Water as a Fuel, Chem. Comm. 50, 3067-3070.

12 Huang S.Y., Ganesan P., Park S., Popov B.N. (2009) Development of a Titanium Dioxide-Supported Platinum Catalyst with Ultrahigh Stability for Polymer Electrolyte Membrane Fuel Cell Applications, J. Am. Chem. Soc. 131, 13898.

13 Orilall M.C., Matsumoto F., Zhou Q., Sai H., Abrũna H.D., DiSalvo F.J., Wiesner U. (2009) One-Pot Synthesis of Platinum-Based Nanoparticles Incorporate into Mesoporous Niobium Oxide-Carbon Composites for Fuel Cell Electrodes, J. Am. Chem. Soc. 131, 9389.

14 Sun Y., Zhuang L., Lu J., Hong X., Liu P. (2007) Collapse in Crystalline Structure and Decline in Catalytic Activity of Pt Nanoparticles on Reducing Particle Size to $1 \mathrm{~nm}, \mathrm{~J}$. Am. Chem. Soc. 129, 15465.

15 Wang L.L., Johnson D.D. (2007) Shear Instabilities in Metallic Nanoparticles: Hydrogen-Stabilized Structure on $\mathrm{Pt}_{37}$ on Carbon, J. Am. Chem. Soc. 129, 3658.

16 Izumi Y., Nagamori H., Kiyotaki F., Masih D., Minato T., Roisin E., Candy J.P., Tanida H., Uruga T. (2005) X-ray Absorption Fine Structure Combined with X-ray Fluorescence Spectrometry. Improvement of Spectral Resolution at the Absorption Edges of 9-29 keV, Anal. Chem. 77, 6969.

17 Hanna M.C., Nozik A.J. (2006) Solar Conversion Efficiency of Photovoltaic and Photoelectrolysis Cells with Carrier Multiplication Absorbers, J. Appl. Phys. 100, 074510.

18 Morikawa M., Ogura Y., Ahmed N., Kawamura S., Mikami G., Okamoto S., Izumi Y. (2014) Photocatalytic Conversion of Carbon Dioxide into Methanol in Reverse Fuel Cells with Tungsten Oxide and Layered Double Hydroxide Photocatalysts for Solar Fuel Generation, Catal. Sci. Technol. 4, 1644.

19 Heller A. (1981) Conversion of Sunlight into Electrical Power and Photoassisted Electrolysis of Water in Photoelectrochemical Cells, Acc. Chem. Resear. 14, 154.

20 Chen F., Liu H., Bagwasi S., Shen X., Zhang J. (2010) VisibleLight Responsive Photocatalytic Fuel Cell Based on $\mathrm{WO}_{3} / \mathrm{W}$ Photoanode and $\mathrm{Cu}_{2} \mathrm{O} / \mathrm{Cu}$ Photocathode for Simultaneous Wastewater Treatment and Electricity Generation, Environ. Sci. Technol. 46, 11451. 
21 Fujishima Y., Okamoto S., Yoshiba M., Itoi T., Kawamura S., Yoshida Y., Ogura Y., Izumi Y. (2015) Photofuel Cell Comprising Titanium Oxide and Bismuth Oxychloride $\left(\mathrm{BiO}_{1-x} \mathrm{Cl}_{1-y}\right)$ Photocatalysts for Use of Acidic Water as a Fuel, J. Mater. Chem. A. 3, 8389.

22 Moberg L., Karlberg B. (2000) An Improved $N$, $N^{\prime}$-Diethyl- $p$ Phenylenediamine (DPD) Method for the Determination of Free Chlorine Based on Multiple Wavelength Detection, Anal. Chim. Acta 407, 127.

23 Battino R., Rettich T.R., Tominaga T. (1983) The Solubility of Oxygen and Ozone in Liquids, J. Phys. Chem. Ref. Data 12, 163.

24 Anderson A.Y., Barnes P.R.F., Durrant J.R., O'Regan B.C. (2011) Quantifying Regeneration in Dye-Sensitized Solar Cells, J. Phys. Chem. C 115, 2439.

25 Hu Z.T., Liu J., Yan X., Oh W.D., Lim T.T. (2015) LowTemperature Synthesis of Grapheme/ $\mathrm{Bi}_{2} \mathrm{Fe}_{4} \mathrm{O}_{9}$ Composite for Synergistic Adsorption-Photocatalytic Degradation of Hydrophobic Pollutant under Solar Irradiation, Chem. Eng. J. 262, 1022.

26 Wu W., Huang Z.H., Lim T.T. (2014) Recent Development of Mixed Metal Oxide Anodes for Electrochemical Oxidation of Organic Pollutants in Water, Appl. Catal. A. 480, 58.
27 Nath R.K., Zain M.F.M., Kadhum A.A.H. (2014) Artificial Photosynthesis using $\mathrm{LiNbO}_{3}$ as Photocatalyst for Sustainable and Environmental Friendly Construction and Reduction of Global Warming: A Review, Catal. Rev. Sci. Eng. 56, 175.

28 Swierk J.R., Mallouk T.E. (2013) Design and Development of Photoanodes for Water-Splitting Dye-Sensitized Photoelectrochemical Cells, Chem. Soc. Rev. 42, 2357.

29 Wenyi T., Qin Z., Han Y., Xiufang Z., Hongyi L. (2012) Deactivation Anode Catalyst $\mathrm{La}_{0.75} \mathrm{Sr}_{0.25} \mathrm{Cr}_{0.5} \mathrm{Mn}_{0.5} \mathrm{O}_{3+\delta}$ in SOFC with Fuel Containing Hydrogen Sulfur: The Role of Lattice Oxygen, Int. J. Hydrogen Energy 37, 7398.

Manuscript submitted in October 2014 Manuscript accepted in September 2015

Published online in October 2015

Cite this article as: Y. Ogura, M. Yoshiba and Y. Izumi (2015). Recyclable PhotoFuel Cell for Use of Acidic Water as a Medium, Oil Gas Sci. Technol 70, 5, 853-862. 